H.-D. ARNDT,* S. RIZZO, C. NÖCKER, V. N. WAKCHAURE, L.-G. MILROY, V. BIEKER, A. CALDERON, T. T. N. TRAN, S. BRAND, L. DEHMELT, H. WALDMANN* (EINDHOVEN UNIVERSITY OF TECHNOLOGY, THE NETHERLANDS; TU DORTMUND, MAX-PLANCKINSTITUT FÜR MOLEKULARE PFLANZENPHYSIOLOGIE, DORTMUND AND FRIEDRICHSCHILLER-UNIVERSITÄT, JENA, GERMANY)

Divergent Solid-Phase Synthesis of Natural Product-Inspired Bipartite Cyclodepsipeptides: Total Synthesis of Seragamide A

Chem. Eur. J. 2015, 21, 5311-5316.

\title{
SPS of Seragamide A via Relay-Ring-Closing Metathesis
}

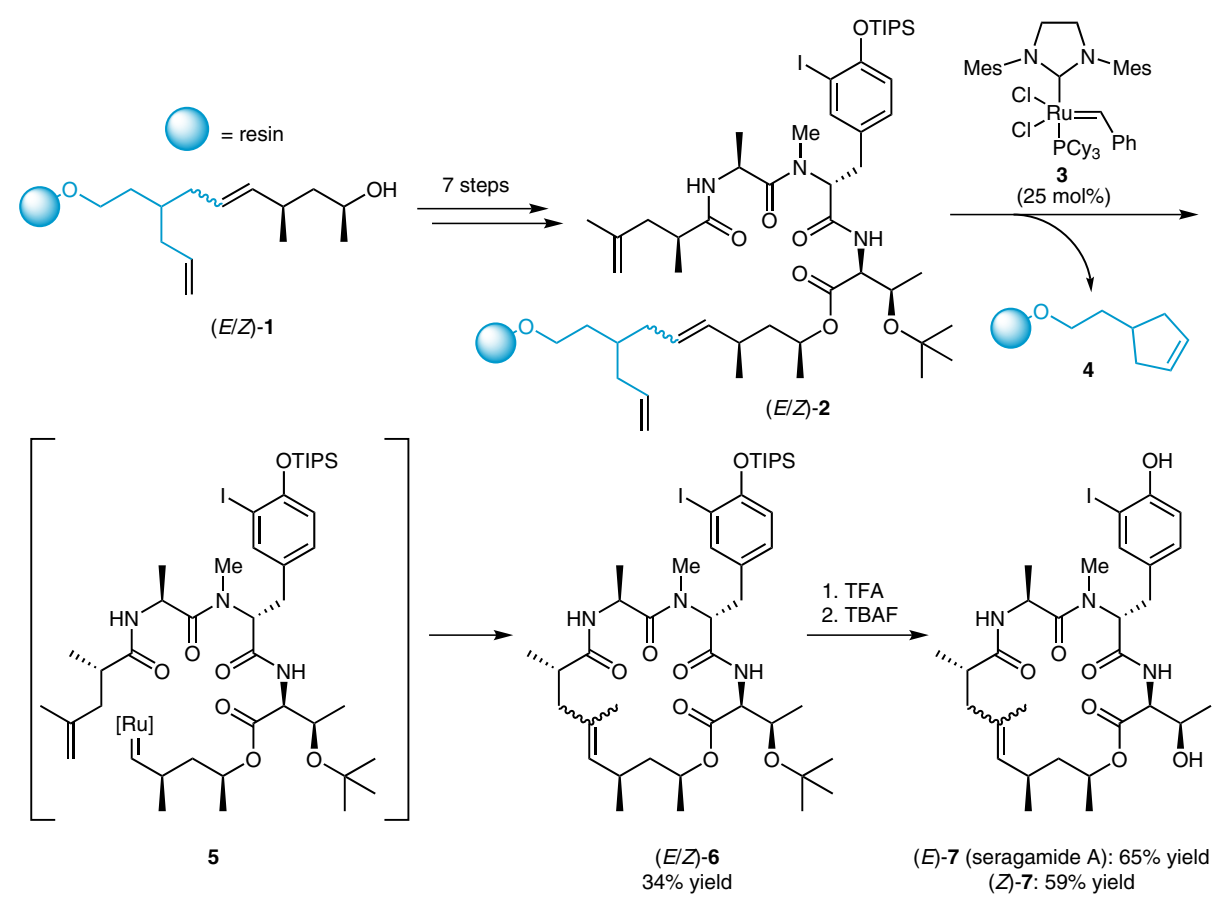

Significance: The authors present the first total synthesis of seragamide A (isolated from the sponge Suberites japonicus Thiele in 2006) via a solid-phase synthesis-cyclorelease strategy utilizing relay-ring-closing metathesis. Starting from resin $(E / Z)-\mathbf{1}$, the precursor $(E / Z)-\mathbf{2}$ was prepared in seven steps. Relay-ring-closing metathesis of $(E / Z)-2$ proceeded in the presence of $\mathrm{RuCl}_{2}(\mathrm{SIMes})\left(\mathrm{PCy}_{3}\right)(=\mathrm{CHPh})(\mathbf{3})$ to give $(E / Z)-\mathbf{6}$ in $34 \%$ yield based on (E/Z)-1 as a mixture of separable isomers. Treatment of (E)-6 with TFA followed by TBAF provided $(E)-7$ (seragamide $A$ ) in 65\% yield (based on the crucial ring-closing step). Similarly, (Z)-6 was converted into (Z)-7 in 59\% yield.
Comment: The present synthetic protocol was also applied to the preparation of a collection of structurally diverse cyclodepsipeptides using various peptides ( 9 examples) and ketide segments (4 examples). 